\title{
ANALISIS BIAYA VOLUME LABA MELALUI ALOKASI \\ BIAYA BERSAMA SEBAGAI PERENCANAAN LABA
}

\author{
Sri Wahyuni \\ Jurusan Akuntansi STIE Asia Malang \\ JI Rembuksari Soekarno Hatta No. 1 Malang \\ No Telepon: 085233249979, Email: Wahyuni210810@gmail.com
}

\begin{abstract}
Wahyuni, Sri, 2012, Analysis of Cost Volume Profit through cost allocation Profit Planning Together For The Cita Rasa Company Bakery. The purpose of this study was to determine the allocation of shared cost and profit planning analysis should be done of the company. The analysis used is the analysis of BVL, which includes Contribution margin analysis, BEP and margin of safety. The least squares method to separate semi-variable costs into fixed costs and variable costs. Based on the calculation of the analysis has been done to obtain the amount of contribution margin brown bread USD 350.00 / unit, bread, jam USD 360.00 / unit, toast sesame USD 414.00 / unit, bread snow USD 286.00 / unit, raisin bread USD 413.00 / unit, banana bread USD 406.00 / unit and Donat Rp 231.00 / unit. Break even point is found to be U.S. \$17,346,941.00 for brown bread, bread jam 25,349,794.00 USD, USD $20,011,588.00$ sesame bread, buns snow USD 8,673,619.00, raisin bread $R p$ 13,609,900.00 ,banana bread and donuts $R p$ Rp 19,925,143.00 20,011,588.00. While the margin of safety obtained for $92.57 \%$ of the total product mix. Target profit of Rp 300 million a year, the sales target to be achieved by Rp 1,385,941,767.00 company with a sales target of 938,580 units in the unit.Based on the calculation above, it can be concluded that it is better Taste Bakery Bread Company uses BVL in profit planning analysis to facilitate the changes that would occur if the profit there is a change in trace element analysis BVL..
\end{abstract}

Keywords: Joint Costs, Cost Volume Profit, Profit Planning 


\section{PENDAHULUAN}

Perencanaan laba merupakan hal yang sangat penting bagi suatu perusahaan dikarenakan berpengaruh terhadap kelangsungan hidup serta tujuan dari perusahaan tersebut. Perencanaan laba bisa ditentukan dengan melakukan analisis biaya volume laba (BVL). Analisis BVL meliputi analisis tentang contribution margin, break even point, dan margin of safety.

Analisis contribution margin digunakan untuk mengetahui jumlah yang tersedia untuk menutup biaya tetap dan untuk menghasilkan laba. Semakin besar contribution margin, semakin besar kesempatan yang diperoleh perusahaan untuk menutup biaya tetap dan untuk menghasilkan laba. Selanjutnya analisis break even point untuk mengetahui keadaan perusahaan dimana jumlah total pendapatan besarnya sama dengan jumlah total biaya atau pengeluaran. Dengan kata lain, break even point menunjukkan keadaan dimana perusahaan dalam keadaan tidak rugi maupun untung. Sedangkan analisis margin of safety untuk menghitung jumlah dimana penjualan dapat menurun sebelum kerugian mulai terjadi. Semakin tinggi margin of safety maka semakin rendah risiko perusahaan untuk berada pada posisi tidak aman.

Untuk melakukan analisis BVL, ada berbagai informasi keuangan yang diperlukan. Informasi tersebut meliputi biaya produksi hingga pendapatan. Dengan informasi biaya produksi, perusahaan dapat menentukan harga pokok produk. Harga pokok produksi terbentuk dari biaya-biaya yang berhubungan dengan kegiatan produk jadi siap dijual ke pasar. Hal tersebut didukung oleh pendapat Mulyadi (2010:14) bahwa "biaya produksi merupakan biaya-biaya yang terjadi untuk mengolah bahan baku menjadi produk jadi yang siap untuk dijual yang terdiri dari tiga elemen yaitu ; biaya bahan baku, biaya tenaga kerja langsung dan biaya overhead pabrik.

Perusahaan yang mengolah satu macam bahan baku dalam satu proses produksi yang sama untuk menghasilkan dua jenis produk atau lebih, akan membutuhkan pengalokasian biaya pada setiap produk yang dihasilkannya secara tepat. Pada perusahaan dengan karakteristik tersebut akan mengalami kesulitan dalam menelusuri terjadinya biaya selama proses produksi berlangsung, terutama untuk proses produksi bersama. Apabila biaya-biaya tersebut tidak ditelusuri secara tepat maka hal tersebut akan mengakibatkan terjadinya pembebanan biaya yang tidak proporsional pada tiap-tiap produk yang dihasilkan. Sehingga dapat berpengaruh pada harga jual produk, Seperti contohnya perusahaan roti yang menghasilkan berbagai macam roti. Berbagai macam roti yang dihasilkan dari proses produksi bersamaan tersebut dinamakan produk bersama . Sebagaimana yang diungkapkan oleh Dunia (2009:158) produk bersama adalah dua produk atau lebih yang dihasilkan secara simultan dari suatu proses atau melalui serangkaian proses tertentu, dimana masing-masing produk mempunyai nilai penjualan yang relatif besar atau berarti. 
Produk bersama yang dihasilkan dari serangkaian proses produksi yang bersamaan, mengandung unsur biaya bersama yang sulit diidentifikasikan alirannya dari jenis-jenis produk yang dihasilkan. Biaya yang dikeluarkan untuk mengolah dari satu macam bahan baku menjadi berbagai produk dapat berupa produk utama dan produk sampingan disebut biaya bersama. Sebagaimana yang diungkapkan oleh Mulyadi (2010:334) bahwa biaya bersama adalah "biaya yang dikeluarkan sejak saat mula-mula bahan baku diolah sampai dengan saat berbagai macam produk dapat dipisahkan identitasnya".

Dalam perusahaan yang mengolah produk dengan biaya bersama akan mengalami masalah utama dalam penentuan harga pokok produk yang berbeda-beda dari produkproduk yang dihasilkan, terutama untuk produk utama. Harga pokok produk akan berpengaruh pada besarnya kontribusi yang akan diberikan dari produk utama dan produk sampingan terhadap keseluruhan penghasilan perusahan. Dalam hal ini harga pokok produk berhubungan dengan penentuan harga jual untuk produk-produk yang dihasilkan.

Perhitungan harga pokok yang dilakukan secara tidak tepat akan mengakibatkan nilai persediaan dan juga harga pokok yang tercantum dalam laporan rugi-laba menjadi tidak tepat. Alasan utama yang mendasarinya adalah untuk menentukan harga jual yang bersaing.

Apabila perusahaan memperhitungkan harga pokoknya terlalu rendah maka harga jualnya pun dinilai terlalu rendah, yang akan mengakibatkan kerugian pada perusahaan karena tidak dapat menutupi biaya yang telah dikorbankan selama proses produksi. Namun, apabila perusahaan memperhitungkan harga pokoknya terlalu tinggi maka akan mengakibatkan kerugian pada perusahaan karena tidak dapat bersaing dengan hasil produksi yang sejenis lainnya.

Penentuan harga pokok produk yang terdiri dari bahan baku, BTKL, dan BOP dapat menimbulkan permasalahan yang kompleks ketika biaya-biaya tersebut terjadi dalam proses bersama. Alokasi biaya bersama harus dilakukan untuk menjadi solusi dalam masalah tersebut. Salah satu metode yang paling lazim digunakan menurut Mulyadi (2010:336) adalah metode harga pasar. Metodi harga pasar didasarkan atas harga jual dari suatu produk yang merupakan perwujudan dari biaya-biaya yang dikeluarkan dalam mengolah produk tersebut. Sehingga menurut metode ini cara yang logis untuk mengalokasikan biaya bersama adalah berdasarkan nilai pasar masing-masing produk bersama.

Penentuan harga pokok produksi dapat berguna bagi perusahaan, selain dapat mengetahui besarnya biaya produksi yang dikonsumsi tiap-tiap produk, juga dapat berguna untuk pelaporan keuangan perusahaan. Pelaporan keuangan ini diperlukan untuk pelaporan perpajakan, peminjaman ke bank dan pengembangan usaha untuk masa depan. Disamping itu dengan menentukan harga pokok produksi yang tepat, maka perusahaan dapat merencanakan laba yang diinginkan yaitu berapa besar target penjualan dan unit produksi 
yang akan dicapai. Melihat betapa pentingnya alokasi biaya bersama untuk merencanakan laba maka peneliti tertarik untuk mengkaji permasalahan dalam penelitian yang berjudul Analisis Biaya Volume Dan Laba Melalui Alokasi Biaya Bersama Sebagai Perencanaan Laba Pada Perusahaan Roti Cita Rasa Bakery.

Permasalahan yag muncul adalah: (1) Bagaimanakah alokasi biaya bersama dengan menggunakan metode harga pasar untuk menentukan harga pokok produksi yang dilakukan perusahaan roti? (2) Bagaimanakah analisis contribution margin, break even point dan margin of safety yang seharusnya dilakukan oleh perusahaan roti?

\section{LANDASAN TEORI}

\section{Biaya dan Harga Pokok Produksi}

Biaya adalah pengorbanan sumber ekonomi, yang diukur dalam satuan uang, yang telah terjadi atau yang kemungkinan akan terjadi untuk tujuan tertentu. Dalam perusahaan manufaktur klasifikasi biaya ada tiga fungsi pokok yaitu fungsi produksi, fungsi pemasaran dan fungsi administrasi dan umum. Oleh karena itu perusahaan manufaktur, biaya dapat dikelompokkan menjadi tiga kelompok:

1. Biaya Produksi, merupakan biaya-biaya yang terjadi untuk mengolah bahan baku menjadi produk jadi yang siap untuk dijual. Secara garis besar biaya produksi ini dibagi menjadi; biaya bahan baku, biaya tenaga kerja langsung dan biaya overhead pabrik.

2. Biaya pemasaran, merupakan biaya-biaya yang terjadi untuk melaksanakan kegiatan pemasaran.

3. Biaya administrasi dan umum, merupakan biaya-biaya untuk mengkoordinasikan kegiatan produksi dan pemasaran produk.

Menurut Mulyadi (2010:14) "biaya produksi merupakan biaya-biaya yang terjadi untuk mengolah bahan baku menjadi produk jadi yang siap dijual". Selanjutnya menurut Mulyadi (2010:122) ada dua metode perhitungan harga yaitu metode full costing dan metode variabel costing.

\section{Biaya Bersama}

Menurut Carter (2009 : 269) "biaya bersama dapat didefinisikan sebagai biaya yang muncul dari produksi yang simultan atas berbagai produk dalam proses yang sama". Berbeda dengan pendapat Mulyadi (2010 : 333) yang menyatakan bahwa "biaya bersama dapat diartikan sebagai biaya overhead bersama (joint overhead cost) yang harus dialokasikan ke berbagai departemen, baik dalam perusahaan yang kegiatan produksinya berdasarkan pesanan maupun yang kegiatan produksinya dilakukan secara massal". Selanjutnya dua produk atau lebih yang dihasilkan oleh perusahaan dalam satu proses produksi bersamaan maka produk tersebut dinamakan produk bersama. Didalam produk 
bersama mengandung unsure biaya bersama sehingga harus dialokasikan dengan metode sebagai berikut :

1. Metode harga pasar

2. Metode biaya rata-rata per unit

3. Metode unit kuantitatif

4. Metode rata-rata tertimbang

\section{Pengertian Break Even Point}

Suatu perusahaan dapat dikatakan Break Even Point yaitu apabila setelah disusus laporan perhitungan rugi laba untuk suatu periode tertentu perusahaan dengan kata lain laba sama dengan nol atau ruginya sama dengan nol. Hasil penjualan (sales revenue) yang diperoleh untuk periode tertentu sama besarnya dengan keseluruhan biaya (total cost), yang telah dikorbankan sehingga perusahaan tidak menderita kerugian. Menurut Mulyadi (2001:228) "break even point adalah suatu kondisi dimana pada periode tersebut perusahaan tidak mendapatkan keuntungan dan juga tidak menderita kerugian."

\section{Pengertian Contribution Margin}

Menurut Mulyadi (2001:230) "contribution margin adalah kelebihan pendapatan penjualan diatas biaya variabel". Informasi laba kontribusi memberikan gambaran jumlah yang tersedia untuk menutup biaya tetap dan untuk menghasilkan laba. Sedangkan menurut Hansen dan Mowen (2006: 212) "contribution margin adalah pendapatan penjualan dikurangi total biaya variabel".

\section{Pengertian Margin Of Safety}

Analisis margin of safety menunjukkan berapa banyak penjualan yang boleh turun dari jumlah penjualan tertentu dimana perusahaan belum menderita rugi atau dalam keadaan Break Even. Dengan kata lain angka margin of safety memberikan petunjuk jumlah maksimum penurunan angka volume penjualan yang direncanakan yang tidak mengakibatkan kerugian. margin of safety merupakan elemen untuk mengukur keamanan perusahaan. Menurut Mulyadi (2001:229) kelebihan dari penjualan yang dianggarkan (aktual) di atas titik impas volume penjualan. Margin keamanan menjelaskan jumlah dimana penjualan dapat menurun sebelum kerugian mulai terjadi. "Semakin tinggi rasio margin keamanan, semakin rendah resiko untuk tidak balik modal".

\section{Kerangka Konseptual}

Sebagai perusahaan yang profit oriented, tujuan utamanya adalah pencapaian laba yang maksimal. Salah satu strategi yang dilakukan perusahaan adalah dengan merencanakan laba. Laba dipengaruhi oleh tiga faktor yaitu, volume produk yang dijual, harga pokok produksi dan biaya dari tiap-tiap produk yang dihasilkan. Penentuan harga pokok produksi yang tepat memerlukan analisis terhadap masing-masing klasifikasi biaya yang terjadi, meliputi biaya bahan baku, biaya tenaga kerja langsung, dan biaya overhead 
pabrik. Namun demikian, terdapat kesulitan bagi perusahaan yang mengalami proses produksi bersama menggunakan unsur biaya produksi yang sama seperti biaya bahan baku, biaya tenaga kerja langsung dan biaya overhead pabrik.

Hal tersebut di atas dikarenakan tiap-tiap produk mengandung unsur biaya bersama. Untuk itu diperlukan alokasi biaya bersama ke dalam masing-masing produk. Metode yang digunakan dalam mengalokasikan biaya bersama dalam penelitian ini menggunakan metode harga pasar. Metode harga pasar didasarkan pada harga pasar dari tiap-tiap produk yang dihasilkan.

Setelah melakukan alokasi biaya bersama, dapat diketahui jumlah contribution margin dari masing-masing produk bersama terhadap keseluruhan laba yang diperoleh perusahaan sehingga dapat dijadikan bahan analisis break even point sehingga perusahaan dapat menentukan jumlah minimum volume penjualan agar tidak mengalami kerugian. Selanjutnya, informasi total penjualan dan contribution margin juga dapat digunakan untuk menghitung jumlah maksimum (titik aman) penurunan target pendapatan yang boleh terjadi dengan menggunakan analisis margin of safety. Selanjutnya setelah analisi BVL dilakukan maka perusahaan dapat melakukan analisis target laba, untuk menentukan berapa besar target penjualan yang harus dicapai dan berapa unit produk yang harus diproduksi untuk mencapai laba yang diinginkan perusahaan. Untuk mempermudah penjelasan di atas, dapat dilihat pada gambar kerangka konseptual berikut: 
Kerangka Konseptual

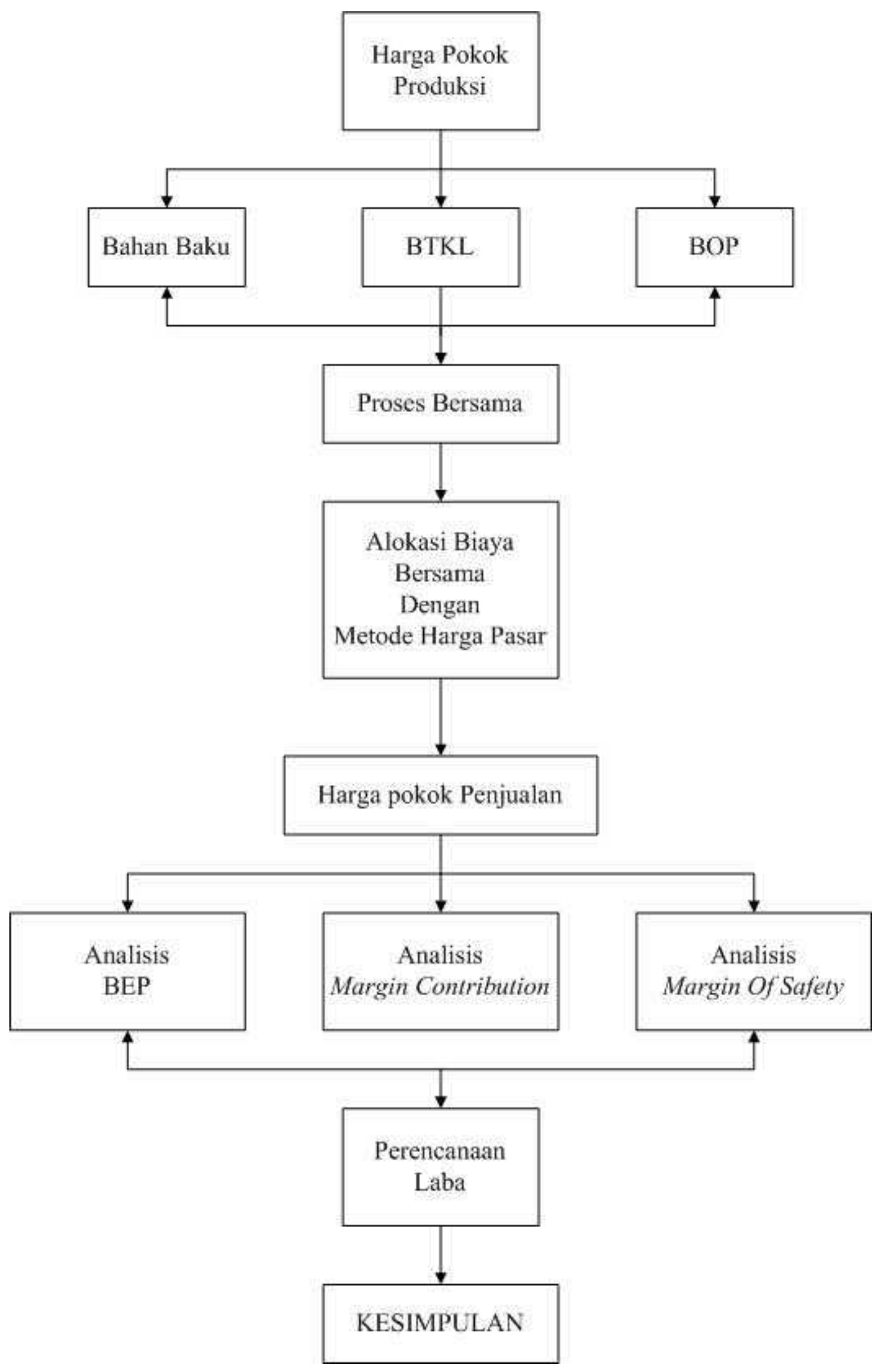




\section{METODE PENELITIAN}

Lokasi penelitian adalah Perusahaan Roti "CITA RASA BAKERY" yang beralamat di Desa Semenpinggir RT 03/03 Kecamatan Kapas, Kabupaten Bojonegoro. Jenis penelitian yang digunakan dalam penelitian ini adalah jenis penelitian studi kasus yang merupakan penelitian dengan karakteristik masalah yang berkaitan dengan latar belakang dan kondisi saat ini dari subyek yang diteliti (Indriantoro dan Supomo, 2009:26). Jenis data yang digunakan adalah data kualitatif dan kuantitatif. Selanjutnya sumber data yang digunakan adalah sumber data primer dan sekunder.

Dalam pembahasan dan dalam rangka mencapai tujuan penulisan ini penulis menggunakan alat analisis berupa analisis kuantitatif, yaitu dengan menggunakan metode sebagai berikut :

1. Penentuan Biaya Bersama:

a. Klasifikasi Biaya, yaitu mengumpulkan seluruh data-data tentang biaya produk bersama yang meliputi biaya bahan baku, biaya tenaga kerja langsung, BOP, data penjualan dan lain sebagainya.

b. Penentuan Proses Bersama (Split Off), menghitung biaya produksi sebelum titik pisah. Selanjutnya melakukan analisis alur proses produksi yang menekankan pada proses dimana pengolahan bahan baku menjadi produk utama. Analisis ini digunakan untuk menentukan titik pisah dari proses produksi tersebut, sehingga alokasi biaya bersama dapat di identifikasi.

c. Metode Harga Pasar

Setelah biaya bersama dapat diidentifikasi, maka selanjutnya dialokasikan ke dalam produk bersama menggunakan metode harga pasar dengan rumus $\begin{aligned} & \text { sebagai berikut : } \\
& \text { Nilai Pasar Hipotetis }\end{aligned}=$\begin{tabular}{|l|l|} 
Nilai Pasar \\
Setelah \\
Proses
\end{tabular}$-\quad$\begin{tabular}{l} 
Pemrosesan \\
Tambahan \\
\hline
\end{tabular}

Alokasi Biaya gabungan:

Nilai Pasar Hipotetis produk tertentu $x \frac{\text { Total Biaya Produksi Gabungan }}{\text { Total Nilai Pasar Hipotetis }}$

d. Menentukan sifat biaya yang termasuk biaya variabel dan biaya tetap serta menentukan standar biaya bahan tambahan, bahan baku, dan biaya overhead pabrik dengan metode least square : 


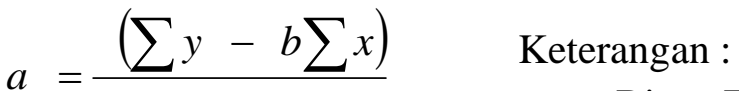

$$
\begin{aligned}
& \text { a : Biaya Tetap } \\
& b=\frac{n \sum x y-\sum x \sum y}{n \sum x^{2}-\left(\sum x\right)^{2}} \\
& \text { b : Biaya Variabel } \\
& \mathrm{n} \text { : Jumlah Periode } \\
& \mathrm{x} \text { : Cost Driver } \\
& \mathrm{y}: \text { Jumlah Biaya Tertentu }
\end{aligned}
$$

\section{Analisis Contribution Margin}

Perhitungan Contribution Margin dapat dinyatakan dalam persamaan sebagai berikut :

Contribution Margin = Harga Jual - Biaya Variabel

Rasio contribution margin dinyatakan dalam persamaan sebagai berikut:

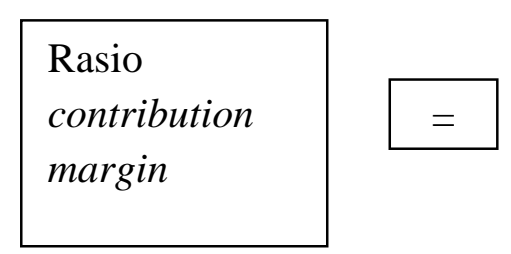

\section{Contribution margin}

Penjualan

3. Analisis Break Event Point (BEP)

Perhitungan BEP dapat dilakukan dengan formula sebagai berikut :

\begin{tabular}{|l|}
\hline BEP (dalam \\
satuan produk \\
yang dijual)
\end{tabular}
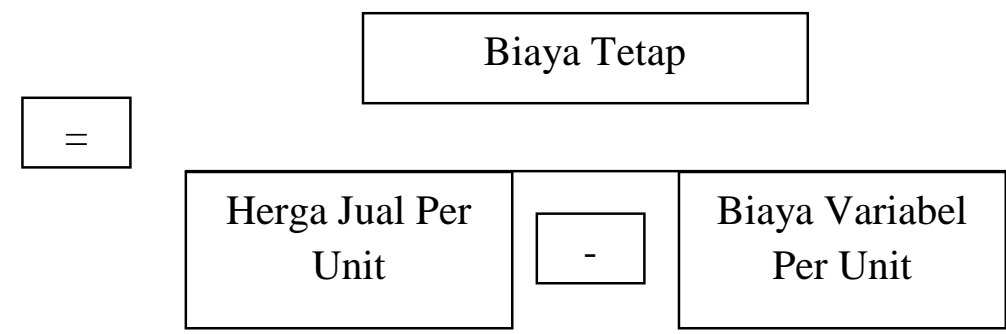

Selanjutnya perhitungan BEP dalam rupiah penjualan adalah sebagai berikut :

BEP (dalam
rupiah
penjualan)

Biaya Tetap

$$
=
$$


4. Analisis Margin Of Safety (MOS)

\section{Rasio}

Contribution

Margin

Untuk menentukan margin of safety digunakan perhitungan sebagai berikut :

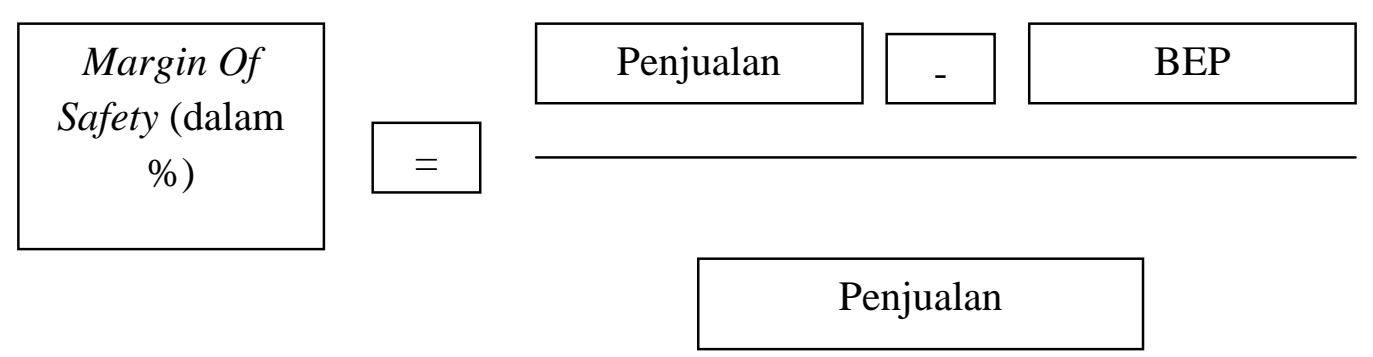

\section{HASIL PENELITIAN DAN PEMBAHASAN}

Perusahaan roti Cita Rasa Bakery adalah perushaan perusahaan yang mengolah bahan baku tepung terigu beserta komponennya menjadi berbagai macam produk olahan roti yang siap di konsumsi oleh konsumen. Perusahaan ini meliki 2 derpartemen yaitu departemen produksi dan departemen penjualan. Pada departemen produksi terdiri dari departemen penggilingan adonan dan departemen pembuatan roti (baker). Departemen penggilingan adonan merupakan departemen pertama yang mengolah bahan baku bersama sebelum titik pisah (split off). Sedangkan departemen pembuatan roti (Baker) merupakan departemen kedua setelah titik pisah (split off) dan merupakan departemen terakhir yang mengolah bahan baku hingga menjadi produk jadi yang siap dijual ke pasar. Berikut adalah jumlah biaya bersama yang terjadi pada departemen penggilingan adonan yaitu sebagai berikut:

Perhitungan Biaya Produksi Bersama Departemen Penggilingan Adonan (Dasar perhitungan tahun 2010 dan 2011 aktual)

\begin{tabular}{|l|c|c|c|c|}
\hline \multicolumn{1}{|c|}{ Bulan } & Bahan Baku & BTKL & BOP & Total \\
& $A$ & $B$ & $C$ & $(a+b+c)$ \\
\hline Januari & $R p 40.366 .900,00$ & $R p 1.525 .000,00$ & $R p 1.086 .099,00$ & $R p 42.977 .999,00$ \\
\hline Februari & $R p 36.906 .880,00$ & $R p 1.394 .000,00$ & $R p 1.084 .084,00$ & $R p 39.384 .964,00$ \\
\hline Maret & $R p 42.673 .580,00$ & $R p 1.612 .000,00$ & $R p 1.087 .443,00$ & $R p 45.373 .023,00$ \\
\hline April & $R p 41.058 .904,00$ & $R p 1.551 .000,00$ & $R p 1.086 .502,00$ & $R p 43.696 .406,00$ \\
\hline Mei & $R p 41.058 .904,00$ & $R p 1.551 .000,00$ & $R p 1.086 .502,00$ & $R p 43.696 .406,00$ \\
\hline
\end{tabular}




\begin{tabular}{|l|r|r|r|r|} 
Juni & $R p 39.444 .228,00$ & $R p 1.490 .000,00$ & $R p 1.085 .562,00$ & $R p 42.019 .790,00$ \\
\hline Juli & $R p 41.981 .576,00$ & $R p 1.586 .000,00$ & $R p 1.087 .040,00$ & $R p 44.654 .616,00$ \\
\hline Agustus & $R p 39.213 .560,00$ & $R p 1.481 .000,00$ & $R p 1.085 .428,00$ & $R p 41.779 .988,00$ \\
\hline September & $R p 33.908 .196,00$ & $R p 1.282 .000,00$ & $R p 1.082 .338,00$ & $R p 36.272 .534,00$ \\
\hline Oktober & $R p 41.981 .576,00$ & $R p 1.586 .000,00$ & $R p 1.087 .040,00$ & $R p 44.654 .616,00$ \\
\hline November & $R p 41.289 .572,00$ & $R p 1.560 .000,00$ & $R p 1.086 .637,00$ & $R p 43.936 .209,00$ \\
\hline Desember & $R p 43.596 .252,00$ & $R p 1.647 .000,00$ & $R p 1.087 .980,00$ & $R p 46.331 .232,00$ \\
\hline TOTAL & $R p 483.480 .128,00$ & $R p 18.265 .000,00$ & $R p 13.032 .654,00$ & $R p 514.777 .782,00$ \\
\hline
\end{tabular}

Dari data biaya bersama diatas maka selanjutnya dapat dilakukan perhitungan alokasi biaya bersama. Dalam penelitian ini metode yang digunakan untuk melakukan alokasi biaya

bersama adalah metode harga pasar. Hasil dari perhitungan alokasi biaya bersama adalah sebagai berikut: 
Cita Rasa Bakery

Alokasi Biaya Bersama Metode Harga Pasar

\begin{tabular}{|c|c|c|c|c|c|c|c|c|c|c|}
\hline PRODUK & $\begin{array}{c}\text { NILAI } \\
\text { PASAR } \\
\text { PER UNIT } \\
\text { STL } \\
\text { PROSES } \\
\\
a\end{array}$ & $\begin{array}{l}\text { JML / } \\
\text { UNIT }\end{array}$ & $\begin{array}{c}\text { TOTAL } \\
\text { NILAI PASAR } \\
\\
(a \times b) \\
\text { C }\end{array}$ & $\begin{array}{c}\text { BIAYA } \\
\text { PEMROSESAN } \\
\text { TAMBAHAN } \\
\text { D }\end{array}$ & $\begin{array}{l}\text { NILAI PASAR } \\
\text { HIPOTETIS } \\
\\
(c-d) \\
E\end{array}$ & $\begin{array}{c}\text { PERSENTASE } \\
\text { BY BERSAMA } \\
\text { (Total by } \\
\text { bersama } \\
\text { : Total kolom } \\
\text { c) } \\
\text { F }\end{array}$ & $\begin{array}{c}\text { PEMBAGIAN } \\
\text { BIAYA } \\
\text { PRODUKSI } \\
(e \times f) \\
g\end{array}$ & $\begin{array}{c}\text { PEMBAGIAN } \\
\text { BIAYA } \\
\text { PRODUKSI } \\
\text { PER UNIT } \\
(g: b)\end{array}$ & $\begin{array}{c}\text { TOT BIAYA } \\
\text { PRODUKSI } \\
\\
(d+g) \\
h\end{array}$ & $\begin{array}{c}\text { PERSENTASE } \\
\text { TOTAL BIAYA } \\
\text { PRODUKSI }\end{array}$ \\
\hline Roti Coklat & Rp1.500 & 155.720 & Rp233.580.000 & Rp107.365.442 & Rp126.214.558,13 & $55,50 \%$ & Rp70.046.709,43 & Rp450 & Rp177.412.151,29 & $75,95 \%$ \\
\hline Roti Selai & Rp1.500 & 227.560 & Rp341.340.000 & Rp151.654.146 & Rp189.685.853,63 & $55,50 \%$ & Rp105.272.086,43 & Rp463 & Rp256.926.232,79 & $75,27 \%$ \\
\hline Roti Wijen & Rp1.500 & 179.640 & Rp269.460.000 & Rp98.012.040 & Rp171.447.960,48 & $55,50 \%$ & Rp95.150.398,24 & Rp530 & Rp193.162.437,76 & $71,69 \%$ \\
\hline Roti Salju & Rp1.300 & 89.840 & Rp116.792.000 & Rp56.877.932 & Rp59.914.068,19 & $55,50 \%$ & Rp33.251.182,65 & Rp370 & Rp90.129.114,46 & $77,17 \%$ \\
\hline Roti Kismis & Rp1.700 & 107.800 & Rp183.260.000 & Rp80.578.078 & Rp102.681.921,65 & $55,50 \%$ & Rp56.986.538,13 & Rp529 & Rp137.564.616,48 & $75,07 \%$ \\
\hline Roti Pisang & Rp1.400 & 191.640 & Rp268.296.000 & Rp88.589.270 & Rp179.706.730,05 & $55,50 \%$ & Rp99.733.860,25 & Rp520 & Rp188.323.130,20 & $70,19 \%$ \\
\hline Donat & Rp1.500 & 179.640 & Rp269.460.000 & Rp171.552.165 & Rp97.907.835,48 & $55,50 \%$ & Rp54.337.009,96 & Rp302 & Rp225.889.174,48 & $83,83 \%$ \\
\hline TOTAL & & 1.131 .840 & Rp1.682.188.000 & Rp754.629.072 & Rp927.558.928 & $55,50 \%$ & Rp514.777.785 & & Rp1.269.406.857 & $75,462 \%$ \\
\hline
\end{tabular}

- Persentase Biaya Bersama = Total Biaya produksi bersama

Total Nilai Pasar Hipotesis

$=\underline{\operatorname{Rp} 514.777 .785}=55,50 \%$

Rp927.558.928 
Dari perhitungan alokasi biaya bersama dengan metode harga pasar diperoleh hasil persentase paling tinggi yaitu donat sebesar $83,83 \%$, hal ini dikarenakan pembagian biaya produksi per unit paling rendah yaitu sebesar Rp 302,00. Hal ini sesuai dengan tingkat penjualan roti pisang yang paling tinggi selama 2 tahun terakhir. Selanjutnya hasil perhitungan contribution margin adalah sebagai berikut :

\section{Cita Rasa Bakery}

Perhitungan Contribution Margin Tiap-Tiap Produk/Unit

\begin{tabular}{|c|c|c|c|c|c|c|c|c|}
\hline $\begin{array}{c}\text { Nama } \\
\text { Produk }\end{array}$ & $\begin{array}{c}\text { Harga } \\
\text { Jual }\end{array}$ & $\begin{array}{c}\text { Bahan Baku } \\
\text { Standar/unit } \\
2\end{array}$ & $\begin{array}{l}\text { BTKL } \\
\text { Standar/ } \\
\text { unit } \\
3\end{array}$ & $\begin{array}{c}\text { BOP } \\
\text { Variabel } \\
\text { Standar/unit } \\
4\end{array}$ & $\begin{array}{c}\text { Biaya } \\
\text { Penjualan } \\
\text { Variabel } \\
\text { Standar/unit } \\
5\end{array}$ & $\begin{array}{l}\text { Total Biaya } \\
\text { Variabel/unit } \\
\text { jumlah } 2 \text { s/d } \\
5\end{array}$ & $(1-6)$ & $\begin{array}{c}\text { Rasio } \\
\text { CM } \\
(\%)\end{array}$ \\
\hline Roti Coklat & Rp1.500 & Rp1.078 & Rp31,8 & $\mathrm{Rp} 7,9$ & Rp32,64 & Rp1.150 & Rp350 & $23.31 \%$ \\
\hline Roti Selai & Rp1.500 & Rp1.068 & Rp31,8 & $\mathrm{Rp} 7,9$ & Rp32,64 & Rp1.140 & Rp360 & $23.99 \%$ \\
\hline Roti Wijen & Rp1.500 & Rp1.014 & Rp31,8 & Rp7,9 & Rp32,64 & Rp1.086 & Rp414 & $27.57 \%$ \\
\hline Roti Salju & Rp1.300 & Rp942 & Rp31,8 & $\mathrm{Rp} 7,9$ & Rp32,64 & Rp1.014 & Rp286 & $21.97 \%$ \\
\hline Roti Kismis & Rp1.700 & Rp1.215 & Rp31,8 & $\mathrm{Rp} 7,9$ & Rp32,64 & Rp1.287 & Rp413 & $24.28 \%$ \\
\hline Roti Pisang & Rp1.400 & Rp921 & Rp31,8 & $\mathrm{Rp} 7,9$ & Rp32,64 & Rp994 & Rp406 & $29.01 \%$ \\
\hline Donat & Rp1.500 & Rp1.196 & Rp31,8 & Rp7,9 & Rp32,64 & Rp1.269 & Rp231 & $15.43 \%$ \\
\hline $\begin{array}{l}\text { RATA- } \\
\text { RATA }\end{array}$ & Rp1.483 & & & & & Rp1.134 & Rp351 & \\
\hline
\end{tabular}

Selanjutnya perhitungan Break Even Point pada perusahaan roti CITA RASA BAKERY adalah sebagai berikut :

$$
\begin{array}{ll}
\text { BEP }(\mathrm{rp})= & \frac{\text { Total CM }}{\text { Total FC }} \\
& =\frac{\text { Rp400.199.144,00 }}{\text { Rp29.720.999,00 }} \\
\text { BEP }= & \text { Rp124.928.573,00 }
\end{array}
$$


Dari perhitungan diatas besarnya titik impas / Break Even Point dari berbagai komposisi produk adalah sebesar Rp. 124.928.573,00. Sedangkan untuk besarnya Break Even Point (unit) akan tampak pada perhitungan di bawah ini :

BEP/(unit) $=\frac{\text { Biaya Tetap }}{\text { CM }}$
$=\frac{\text { Rp29.720.999 }}{\text { Rp351 }}$
BEP (unit) $=\quad 84.603$

Untuk Break Even Point dari masing-masing produk berdasarkan perhitungan diatas adalah sebagai berikut: 


\begin{tabular}{|l|r|r|}
\hline \multicolumn{1}{|c|}{ Produk } & BEP (rp) & BEP (unit) \\
\hline Roti Coklat & Rp17.346.941,00 & 11.565 \\
Roti Selai & Rp25.349.794,00 & 16.900 \\
Roti Wijen & Rp20.011.588,00 & 13.341 \\
Roti Salju & Rp8.673.619,00 & 6.672 \\
Roti Kismis & Rp13.609.900,00 & 8.006 \\
Roti Pisang & Rp19.925.143,00 \\
Donat & Rp20.011.588,00 & 14.232 \\
\hline Total & Rp124.928.573,00 & 13.341 \\
\hline
\end{tabular}

Sedangkan analisis margin of safety yang merupakan elemen untuk mengukur keamanan perusahaan, diperoleh hasil sebagai berikut :

$$
\begin{aligned}
\text { MOS }(\%)= & \frac{\text { Penjualan }- \text { Biaya Tetap }}{\text { Penjualan }} \\
= & \text { Rp1.682.188.000 - Rp29.720.999 }
\end{aligned}
$$

$\operatorname{MOS}(\%) \quad 92.57 \%$

Perusahaan roti CITA RASA BAKERY mentargetkan laba untuk periode tahun 2012 sebesar Rp. 300.000.000.-. Maka perhitungannya adalah sebagai berikut:

Target laba tahun 2012
Biaya Tetap

RCM

Target Penjualan
Rp300.000.000

Rp29.720.999

$23.79 \%$

$$
\begin{aligned}
& =\frac{\text { Biaya Tetap }+ \text { Target Laba }}{\text { CMR }} \\
& =\frac{\text { Rp29.720.999 }+ \text { Rp300.000.000 }}{23.79 \%}
\end{aligned}
$$

$=$
Harga/ unit (Bauran produk)

By. Variabel/unit (Bauran produk)

Target Penjualan (unit)
Rp1.486

Rp1.134

$=\quad$ Biaya Tetap + Target Laba 
Harga/unit - By. Variabel/unit

$=\frac{R p 29.720 .999+R p 300.000 .000}{R p 1.486}+\frac{R p 1.134}{}$
$=938.580$ unit




\section{SIMPULAN}

Berdasarkan hasil penelitian dan pembahasan yang telah diuraikan, maka dapat disimpulkan bahwa : (1) Metode alokasi biaya bersama yang paling tepat digunakan oleh perusahaan adalah Metode harga pasar, hal ini disebabkan karena metode ini dirasa memiliki banyak keunggulan seperti menggunakan dasar alasan bahwa harga pasar mencerminkan besarnya biaya yang diserap oleh setiap macam produk utama, metode ini mudah dipakai sehingga merupakan metode yang populer dan banyak digunakan, selain itu harga pasar dipakai apabila produk utama masih memerlukan proses pengolahan lebih lanjut setelah dapat dipisah dengan produk utama lainnya sesuai dengan kondisi perusahaan, (2) Dari alokasi biaya bersama dapat diketahui bahwa penyerapan biaya bersama terhadap total biaya produksi sebelum titik pisah (Split Off Point) dari masingmasing produk yaitu untuk roti coklat $\mathrm{Rp} 72.261 .197,18$, roti selai $\mathrm{Rp} 108.600 .204,88$, roti wijen $\mathrm{Rp}$ 98.158.525,15, roti salju $\mathrm{Rp} 34.302 .400,29$, roti kismis $\mathrm{Rp} 58.788 .135,83$, roti pisang $\mathrm{Rp}$ 102.886.890,76, dan donat Rp 39.780.430,98, (3) CM (Contribution Margin) dalam tiap-tiap produk bersama yang dapat diketahui setelah perhitungan adalah untuk roti coklat Rp 350,00/unit, roti selai $\mathrm{Rp} \mathrm{360,00/unit,} \mathrm{roti} \mathrm{wijen} \mathrm{Rp} 414,00 /$ unit, roti salju $\mathrm{Rp}$ 286,00/unit, roti kismis Rp 413,00/unit, roti pisang Rp 406,00/unit dan Donat Rp 231,00/unit. (4) Break even point dalam tiap-tiap produk yang dapat diketahui setelah perhitungan adalah untuk roti coklat $\mathrm{Rp} 17.346 .941,00$, roti selai $\mathrm{Rp} 25.349 .794,00$, roti wijen $\mathrm{Rp} 20.011 .588,00$, roti salju $R p$ 8.673.619,00, roti kismis $R p$ 13.609.900,00, roti pisang $R p$ 19.925.143,00 dan donat $\mathrm{Rp} 20.011 .588,00$. Sedangkan break even point dalam unit yaitu untuk roti coklat 11.565 unit, roti selai 16.900 unit, roti wijen 13.341 unit, roti salju 6.672 unit, roti kismis 8.006 unit, roti pisang 14.232 unit dan donat 13.341 unit. (5) Margin of safety yang diketahui setelah perhitungan yaitu sebesar $92,57 \%$ dari keseluruhan bauran produk. (6) Target laba yang yang diinginkan perusahaan yaitu sebesar Rp 300.000 .000 selama satu tahun. Dari target laba tersebut maka target penjualan yang harus dicapai perusahaan yaitu sebesar Rp 1.385.941.767,00 dengan target penjualan dalam unit yaitu sebesar 938.580 unit

\section{DAFTAR PUSTAKA}

Carter dan Usry, 2006, Akuntansi Biaya, Edisi Tiga Belas, Salemba Empat; Jakarta

Carter, William K, 2009, Cost Accounting, Edisi Empat Belas, Salemba Empat; Jakarta

Dahlia, HB, 2011, Analisis Biaya-Volume-Laba sebagai alat bantu dalam perencanaan laba PT Pabrik Gula Takalar, Universitas Hasanuddin: Makasar 
Dunia, Ahmad Firdaus dan Wasilah, 2009, Akuntansi Biaya. Edisi Dua. Salemba Empat; Jakarta

Hansen dan Mowen, 2006, Akuntansi Manajemen, Salemba Empat; Jakarta

Horngren, Charles T. Srikant M. Datar dan George Foster, 2005, Akuntansi Biaya Penekanan Manajerial, Edisi ke sebelas, Indeks; Jakarta

Indriantoro, Nur dan Bambang Supomo, 2009, Metodologi Penelitian Bisnis Untuk Akuntansi dan Manajemen, BPFE; Yogyakarta

Mulyadi, 2010, Akuntansi Biaya, Edisi Lima, Salemba Empat; Jakarta

Mulyadi, 2001, Akuntansi Manajemen, Salemba Empat; Jakarta

Qodariyah, Lailatul, 2006. Analisis biaya bersama guna menentukan harga produk utama dan produk sampingan pada PT. Perkebunan Nusantara X (PERSERO) PG. Ngadiredjo Kediri. Universitas Muhammadiyah Malang: Malang

Soemarso, S.R., 2004, Akuntansi Suatu Pengantar, Edisi Lima, Salemba Empat; Jakarta.

Supriyono. R. A, 2002, Akuntansi Biaya Pengumpulan Biaya dan Penentuan Harga Poko, Edisi Dua, BPFE; Yogyakarta

Susilowati, Anis. 2007. Pemilihan metode alokasi biaya bersama dalam penentuan harga pokok produk per unit pada perusahaan penggilingan padi "Margo Mulyo" di Singopuran Kartasura. Universitas Muhammadiyah Surakarta: Surakarta

Wijaya, Venny, 2011. Analisis biaya, volume dan laba sebagai alat perencanaan laba pada PT CITRALINK KARYA BERLIAN, Universitas Muhammadiyah Malang: Malang

Winanta, Rudi., 2011. Analisis pengalokasian biaya bersama (common cost) dalam penentuan harga pokok produksi keripik (studi kasus pada UKM istana keripik ibu mery). Universitas Lampung: Lampung 